\title{
Respon Mahasiswa IPA IAIN Ponorogo terhadap Pembelajaran Daring Bioteknologi melalui PjBL dengan Konteks Berpikir Kreatif
}

\author{
Eni Lestari $1^{*}$, Rahmi Faradisya Ekapti ${ }^{2}$ \\ ${ }^{1,2}$ Tadris Ilmu Pengetahuan Alam, FATIK, IAIN Ponorogo \\ *e-mail: enilestari1608@gmail.com
}

\begin{abstract}
Abstrak. Pembelajaran daring memiliki banyak tantangan tanpa terkecuali pada mata kuliah Bioteknologi di IAIN Ponorogo. Bioteknologi merupakan pemanfaatan makhluk hidup yang direkayasa untuk dapat meningkatkan kesejahteraan manusia. Ketika pembelajaran daring sulit untuk melakukan pembelajaran secara efektif. Salah satu model yang sesuai untuk diterapkan ketika pembelajaran daring yaitu Project Based Learning (PjBL). Metode yang digunakan dalam penelitian ini adalah deskriptif kuantitatif. Teknik pengumpulan dilakukan dengan menggunakan kuesioner. Penerapan model yang sesuai ketika pembelajaran daring dapat memaksimalkan hasil dari kegiatan belajar mengajar khususnya kemampuan berpikir peserta didik. Penggunaan model pembelajaran yang tepat juga dapat digunakan untuk mencapai tujuan pendidikan khususnya ketika masa pandemi Covid-19. Berdasarkan hasil penelitian, model pembelajaran PjBL mampu meningkatkan kemampuan berpikir kreatif mahasiswa IPA di IAIN Ponorogo dilihat dari indikator kreativitas berupa kelancaran dalam berpikir (fluency), keluwesan (flexibility), elaborasi (ellaboration), dan orgininalitas (originality). Mahasiswa IPA mampu menemukan ide-ide baru terkait produk bioteknologi mulai dari olahan makanan hingga pertanian. Keberhasilan mahasiswa IPA dalam membuat produk olahan bioteknologi memberikan mereka ide untuk mengembangkannya dalam bidang wirausaha dan penelitian lanjutan untuk kedepannya.
\end{abstract}

Kata kunci: pembelajaran daring, bioteknologi, project based learning, berpikir kreatif

Abstract. Online learning has many challenges without exception in the Biotechnology course at IAIN Ponorogo. Biotechnology is the using of living things that are engineered to improve human welfare. When online learning is difficult to do learning effectively. One model that is suitable to be applied when online learning is Project Based Learning $(P j B L)$. The method used in this research is descriptive quantitative. The collection technique is done by using a questionnaire. The application od the appropriate model when online learning can maximize the results of teaching and learning activities, especially the thinking ability of students. The using of appropriate learning models can also be used to achieve educational goals, especially during the Covid-19 pandemic. Based on the results of the research, the PjBL learning model is able to improve the creative thinking skills of science students at IAIN Ponorogo seen from the creativity indicators in the form of fluency, flexibility, elaboration, and originality. Science students are products ranging from processed foods to agriculture. The success of science students in making processed Biotechnology products gives them ideas to develop them in the field of entrepreneurship and further research for the future.

Keywords: online learning, biotechnology, project based learning, creative thinking 


\section{PENDAHULUAN}

Pendidikan merupakan sarana untuk membentuk sumber daya manusia yang bermutu dan berdaya saing. Menurut Permendikbud No. 103 tahun 2014, pendidikan diartikan sebagai suatu usaha sadar dan terencana untuk mewujudkan suasana belajar dan proses pembelajaran agar siswa menjadi aktif untuk mengembangkan potensi dalam dirinya guna memiliki kekuatan spiritual keagamaan, pengendalian diri, kepribadian, kecerdasan, dan akhlak mulia serta keterampilan untuk dirinya, masyarakat, bangsa, dan negara (Kemendikbud, 2014). Dengan adanya pendidikan yang berkualitas diharapkan mampu membentuk lulusan yang berkompetensi baik dari segi pengetahuan dan keterampilan.

Keterampilan proses sains peserta didik tanpa terkecuali mahasiswa saat ini masih cenderung rendah. Keterampilan proses sains hanya berorientasi pada hasil belajar yang mengakibatkan kemampuan mahasiswa dalam hal observasi, interpretasi, klasifikasi, prediksi serta hipotesa menjadi kurang berkembang. Menurut Rahayu (dalam Chasanah, Khoiri, \& Nuroso, 2016) sains bukan hanya berupa penguasaan dan pemahaman mengenai kumpulan pengetahuan berupa fakta, konsep, dan prinsip melainkan juga terdapat proses penemuan.

Mahasiswa sebagai agen perubahan atau agent of change, mahasiswa diharapkan mampu untuk menguasai kemampuan atau skill abad 21 agar mampu bersaing dengan dunia global. Menurut Fadel (dalam Antika \& Nawawi, 2017), keterampilan yang menjadi fokus utama dalam dunia kerja pada abad 21, yaitu: 1) berpikir kritis dan pemecahan masalah, 2) kreativitas dan inovasi, 3) kolaborasi dan kerjasama tim, 4) pemahaman mengenai lintas kebudayaan, 5) komunikasi dan literasi media, 6) kemampuan komputerisasi dan ICT, serta 7) karir dan kemandirian.

Keterampilan berpikir kreatif menjadi sesuatu yang sangat penting untuk dikuasai mahasiswa agar mampu bersaing di dunia kerja pada abad 21 ini.
Menurut Ismayani (2016) mengemukakan bahwa kreativitas merupakan produk dari konstruksi ide kreatif.

Proses berpikir kreatif merupakan suatu proses ketika seseorang dapat menghasilkan solusi permasalahan atau berupa produk kreatif. Menurut Baer (dalam Antika \& Nawawi, 2017) menjelaskan bahwa berpikir kreatif disamakan dengan berpikir divergen. Indikator dalam berpikir divergen dibagi menjadi 4 (empat), yaitu: fluence (menghasilkan banyak ide dari hasil pemikiran), flexibility (menghasilkan ide yang bervariasi), originality (menghasilkan ide baru yang belum ada sebelumnya), serta elaboration (mengembangkan ide yang dimiliki sehingga dapat menghasilkan ide yang lebih rinci).

Kemampuan berpikir kreatif diartikan sebagai kemampuan seseorang untuk melahirkan sesuatu yang baru, baik berupa gagasan maupun dalam bentuk karya nyata yang relatif berbeda dengan yang sudah ada sebelumnya (Harahap, 2020). Menurut Noviyana (2017) menjelaskan berpikir kreatif diartikan sebagai suatu proses berpikir yang menghasilkan ide dan cara secara luas dan beragam dalam menyelesaikan suatu permasalahan, apabila menerapkan berpikir kreatif akan menghasilkan banyak ide yang berguna dalam penyelesainnya. Sedangkan menurut Ismayani (2016) mengemukakan bahwa kreativitas merupakan produk dari konstruksi ide kreatif yang muncul sebagai akibat dari proses berpikir atau dari segi aspek kognitif seseorang.

Berdasarkan pendapat tersebut dapat disimpulkan bahwa kemampuan berpikir kreatif adalah kemampuan seseorang untuk menghasilkan produk berupa gagasan yang dapat digunakan untuk menyelesaikan masalah. Namun dalam penerapan pembelajaran masih terdapat kesulitan untuk mengembangkan kreativitas siswa.

Menurut Beghetto (dalam Siswono, 2016), menjelaskan mengenai kendalakendala yang dialami dalam pengembangan kreativitas di kelas, yaitu praktek pengajaran yang konvergen, 
sikap dan keyakinan pendidik terhadap kreativitas, motivasi lingkungan, dan keyakinan peserta didik itu sendiri terhadap kreativitas.

Salah satu upaya yang dapat dilakukan untuk dapat menyiapkan generasi muda khususnya mahasiswa yang berkualitas dan siap bersaing di dunia kerja ialah dengan pemberlakuan kurikulum yang tepat. Menurut UndangUndang Nomor 20 Tahun 2003, menjelaskan bahwa kurikulum merupakan seperangkat rencana dan pengaturan mengenai tujuan, isi, dan bahan pelajaran beserta dengan cara yang digunakan sebagai pedoman dalam penyelenggaraan kegiatan pembelajaran untuk mencapai tujuan pendidikan (Kemendikbud, 2018). Oleh karena itu, tenaga pendidik harus memahami proses pembelajaran yang sesuai untuk diterapkan. Tenaga pendidik dalam hal ini dosen memiliki tanggungan untuk dapat mengembangkan kemampuan mahasiswa terutama di masa pandemi dengan memilih dan menerapkan model pembelajaran yang tepat.

Model mengajar merupakan salah satu yang harus dikuasai oleh tenaga pendidik dalam pembelajaran (Farihatun \& Rusdarti, 2019). Terdapat bermacammacam model pembelajaran yang dapat digunakan untuk penyampaian materi kepada peserta didik. Sedangkan Trianto (dalam Chasanah, Khoiri, \& Nuroso, 2016) mengemukakan bahwa model pembelajaran adalah suatu pola yang digunakan sebagai pedoman dalam merencanakan pembelajaran dan untuk menentukan perangkat yang dibutuhkan seperti buku, komputer, kurikulum dan lain sebagainya.

Pemilihan model pembelajaran yang tepat dan diperoleh hasil yang sesuai dengan harapan, sehingga peserta didik dapat mencapai tujuan pembelajaran dengan baik. Model pembelajaran yang inovatif merupakan suatu strategi atau cara pembelajaran yang dapat digunakan untuk memberdayakan daya kreativitas mahasiswa. Project Based Learning (PjBL) merupakan salah satu model pembelajaran yang menekankan pada kemampuan berpikir kreatif peserta didik.

Menurut Sani (dalam Budiana, Manuaba, \& Suadnyana, 2016) menjelaskan bahwa model PjBL adalah kegiatan pembelajaran dengan melibatkan peserta didik untuk mengerjakan suatu proyek jangka panjang yang bermanfaat bagi penyelesaian permasalahan di dunia nyata. Sedangkan Mulyadi (2015) menjelaskan bahwa model PjBL adalah model pembelajaran yang memberikan kesempatan kepada pendidik untuk mengelola kegiatan belajar mengajar dengan melibatkan kerja proyek. Yunianta (dalam Rahmazatullaili, Zubainur, \& Munzir, 2017) juga mengemukakan proyek merupakan segala tugas yang diberikan oleh pendidik berdasarkan pertanyaan ataupun permasalahan yang menantang dengan melibatkan peserta didik dalam perancangan, pemecahan masalah, memberikan keputusan, atau aktivitas penyelidikan, memberikan hak secara otonom selama beberapa waktu untuk dapat mengumpulkan dan mengintegrasikan pengetahuan baru dari pengalaman peserta didik ketika beraktivitas secara nyata.

Berdasarkan uraian diatas, peneliti melakukan penelitian untuk mengetahui kemampuan berpikir kreatif mahasiswa IPA IAIN Ponorogo pada proses pembelajaran daring bioteknologi melalui PjBL berdasarkan respon yang mereka berikan.

\section{METODE PENELITIAN}

Berdasarkan latar belakang di atas dari segi tujuan penelitian maka desain penelitian yang digunakan pada penelitian ini adalah deskriptif kuanitatif. Metode deskriptif merupakan prosedur pemecahan masalah yang sedang diselidiki dengan menggambarkan keadaan dari subjek atau objek dalam penelitian berdasarkan fakta dilapangan (Marlinda, 2020). Metode ini digunakan untuk mengetahui respon dari mahasiswa IPA di IAIN Ponorogo setelah melakukan kegiatan pembelajaran daring bioteknologi. Objek penelitiannya ialah 
mahasiswa Jurusan Tadris IPA di IAIN Ponorogo yang telah mendapatkan mata kuliah bioteknologi pada masa pandemi Covid-19 yang berjumlah 13 orang. Instrumen penelitian yang digunakan dengan cara penyebaran kuesioner terhadap objek penelitian. Menurut Sugiyono (dalam Harahap, 2020) kuesioner atau pengumpulan data dilakukan dengan pengisian pertanyaan atau pernyataan dari responden yang kemudian dikembalikan kepada peneliti. Analisis dilakukan dengan mendeskripsikan data yang dikumpulkan berdasarkan respon dari penyebaran kuesioner.

\section{HASIL DAN PEMBAHASAN}

Peneliti melakukan penelitian ini untuk mengetahui kemampuan berpikir kreatif mahasiswa IPA di IAIN Ponorogo setelah melakukan pembelajaran daring selama pandemi Covid-19. Indikator yang menjadi fokus dalam penelitian ini adalah a) lancar dalam mengekspresikan ide atau gagasan baru, b) inovasi produk bioteknologi, c) membuat produk bioteknologi yang unik, d) pengembangan produk yang dihasilkan. Pembahasan hasil dari penelitian ini diupayakan dapat menginterpretasikan hasil wawancara kepada mahasiswa IPA di IAIN Ponorogo yang telah menempuh mata kuliah biotekologi selama masa pandemi Covid19. Berdasarkan hasil wawancara para mahasiswa sudah pernah membuat produk olahan bioteknologi sebelum mendapatkan materi pembelajaran di perguruan tinggi. Hal tersebut dikarenakan ketika di jenjang sekolah menengah sudah pernah dikenalkan dengan materi bioteknologi. Produk yang dihasilkan mereka sebelumnya berupa olahan yang sudah umum di masyarakat. Namun setelah mendapatkan mata kuliah bioteknologi selama pembelajaran daring, mahasiswa IPA mendapatkan inovasi baru mengenai produk dari bioteknologi.

$$
\text { Model pembelajaran yang }
$$

diterapkan oleh tenaga pendidik (dosen) dalam pembelajaran daring bioteknologi berupa Project Based Learning (PjBL) mampu meningkatkan dan mengembangkan kemampuan berpikir kreatif dari mahasiswa IPA IAIN Ponorogo. Hal tersebut dapat diketahui dari kemampuan mahasiswa IPA dalam mencapai indikator dari berpikir kreatif, di antaranya yaitu kelancaran dalam berpikir yang kemudian dapat menghasilkan pemikiran baru atau inovasi mengenai penerapan bioteknologi. Berdasarkan hasil pemikiran baru atau inovasi tersebut mereka mencoba untuk dapat membuat sendiri dari apa yang telah dirancang sebelumnya mengenai produk baru bioteknologi.

\section{Lancar dalam mengekspresikan ide atau gagasan baru}

Lancar dalam mengekspresikan ide atau gagasan baru merupakan indikator yang menunjukkan kreativitas dari mahasiswa IPA dalam pembelajaran ketika mampu menemukan inovasiinovasi baru. Semua responden mengaku telah mengetahui produk bioteknologi sebelum mendapat mata kuliah ini di perguruan tinggi, tetapi hanya sebatas yang sudah beredar di masyarakat luas.

Respon mahasiswa mengenai penemuan ide baru terkait produk bioteknologi dapat dilihat pada Gambar 1.

\section{Menemukan Ide Baru Terkait Produk Bioteknologi}

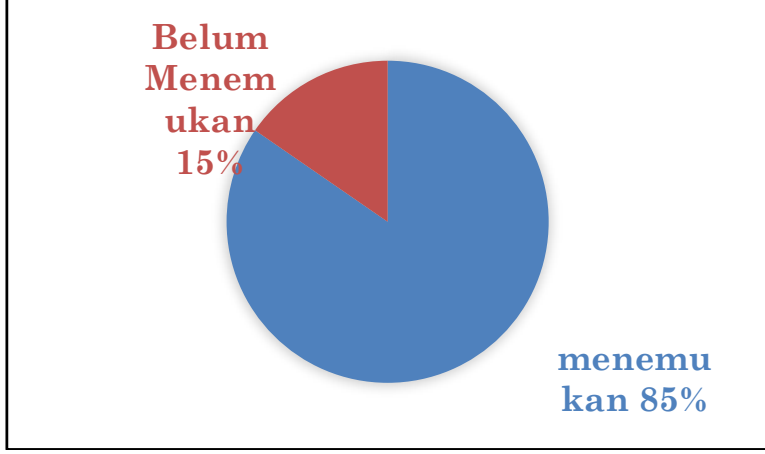

Gambar 1. Respon mahasiswa terkait ide baru dari bioteknologi

Berdasarkan Gambar 1, setelah mengikuti pembelajaran mata kuliah bioteknologi sebanyak $85 \%$ responden dapat menemukan ide-ide berupa inovasi baru mengenai produk olahan dari bioteknologi dengan memanfaatkan bahan yang mudah ditemukan dari lingkungan sekitar. Sedangkan 15\% di 
antaranya belum menemukan ide baru terkait dengan pengaplikasian mata kuliah bioteknologi dalam kehidupan sehari-hari. Mereka hanya melihat produk bioteknologi yang sudah banyak bereda di masyarakat.

\section{Inovasi Produk Bioteknologi}

Inovasi diartikan sebagai suatu pengenalan atau penemuan baru yang berbeda dari yang sudah ada ataupun yang sudah dikenal oleh masyarakat sebelumnya, baik berupa gagasan, metode maupun berupa alat. Dengan adanya inovasi, menunjukkan bahwa manusia mengalami penyesuaian seiring dengan perkembangan zaman yang semakin modern. Adanya inovasi juga menjadi salah satu bukti dari indikator berpikir kreatif berupa kelancaran dalam berpikir (fluence). Berdasarkan hasil penelitian yang telah dilakukan menunjukkan bahwa mahasiswa IPA di IAIN Ponorogo memiliki kelancaran dan keluwesan dalam berpikir yang bagus. Hal tersebut dibuktikan dengan banyaknya ide-ide atau gagasan baru mengenai produk Bioteknologi mulai dari inovasi olahan makanan maupun bidang pertanian.

Respon mahasiswa mengenai bidang inovasi produk Bioteknologi yang berhasil mereka temukan dapat dilihat pada Gambar 2.

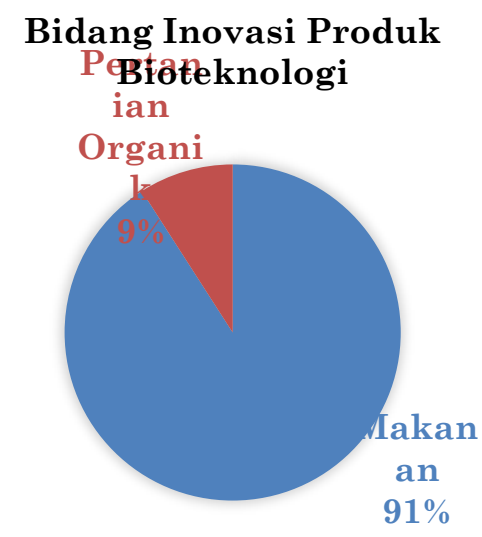

Gambar 1. Bidang produk inovasi dari mahasiswa IPA

Berdasarkan Gambar 2, mahasiswa IPA lebih banyak inovasi pada produk olahan berupa makanan. Sebanyak 83\% responden menyatakan bahwa mereka telah memiliki ide produk olahan makanan untuk direalisasikan. Dengan memanfaatkan bahan sekitar mereka yang mudah untuk diolah namun dengan inovasi dari mereka membuat produk yang dihasilkan memiliki ciri khas tersendiri. Selain itu, adanya fortifikasi pada produk makanan dari mereka membuat produk yang dihasilkan terdapat nilai positif tersendiri jika dibandingkan dengan produk makanan serupa pada umumnya di pasaran. Sedangkan sebanyak $17 \%$ sisanya menyatakan bahwa mereka memilih untuk membuat pupuk organik berdasarkan konsep bioteknologi pertanian dengan bahan-bahan yang ada di sekitar. Hal tersebut membuktikan bahwa mahasiswa IPA memiliki ide inovatif ketika mengikuti pembelajaran mata kuliah bioteknologi.

Respon mahasiswa mengenai inovasi yang berasal dari hasil pemikiran mahasiswa IPA setelah mengikuti pembelajaran bioteknologi secara daring dapat dilihat pada Tabel 1.

Tabel 1. Ide inovasi baru dari mahasiswa IPA

\begin{tabular}{ll}
\hline No & $\begin{array}{l}\text { Ide inovasi baru terkait produk } \\
\text { biotekologi }\end{array}$ \\
\hline 1 & $\begin{array}{l}\text { Pupuk organik cair dari limbah kulit } \\
\text { singkong }\end{array}$ \\
2 & Gabin tapai \\
3 & Milkshake tape ketan hitam \\
4 & Katsu tempe \\
5 & Ice cream tapai ketan hitam \\
6 & Yogurt santan \\
7 & Donat bekatul \\
8 & Tempe GAKUN (mangga sukun) \\
9 & Tempe kacang hijau \\
\hline
\end{tabular}

Berdasarkan Tabel 1, produkproduk yang telah berhasil dibuat oleh mahasiswa IPA tersebut merupakan produk yang belum banyak beredar di pasaran dan masyarakat luas. Munculnya inovasi dari mereka mengenai produk bioteknologi didasari karena adanya pembahasaan materi mengenai hal serupa dalam pembelajaran daring selama pandemi Covid-19. Adanya motivasi dari dosen pengampu ketika menerapkan model PjBL dalam pembelajaran untuk dapat menemukan 
produk-produk baru yang berkaitan dengan penerapan bioteknologi menjadi dorongan bagi mahasiswa IPA untuk dapat mengembangkan kemampuan berpikir kreatif mereka. Akhirnya setelah mengikuti pembelajaran bioteknologi secara daring dengan menggunakan model PjBL mahasiswa IPA di IAIN Ponorogo dapat menghasilkan produk inovatif mengenai bioteknologi.

\section{Produk Bioteknologi yang Unik}

Keluaran dari pembelajaran bioteknologi yang dilaksanakan selama daring ialah pembuatan produk dari konsep yang sudah didapatkan. Adanya proyek untuk menghasilkan produk olahan dari bioteknologi menjadikan mahasiswa IPA lebih termotivasi untuk menghasilkan produk olahan yang berbeda dari yang lain. Indikator dari berpikir kritis atau kreativitas lainnya berupa originalitas. Original yang berarti asli, dalam hal ini berarti produk yang telah dibuat merupakan hasil pemikiran sendiri oleh mahasiswa IPA. Selain menemukan ide-ide berupa inovasi baru terkait dengan produk bioteknologi, mahasiswa IPA juga telah berhasil membuat produk inovasi mereka.

Jenis produk olahan yang berhasil mahasiswa IPA setelah mengikuti pembelajaran mata kuliah bioteknologi dengan model PjBL sangat bervariasi. Namun kebanyakan berasal dari produk makanan dan sisanya berupa pupuk organik cair. Hasil penelitian mengenai produk olahan yang berhasil dibuat oleh mahasiswa IPA selama mengikuti pembelajaran bioteknologi secara daring dapat dilihat pada Gambar 3.

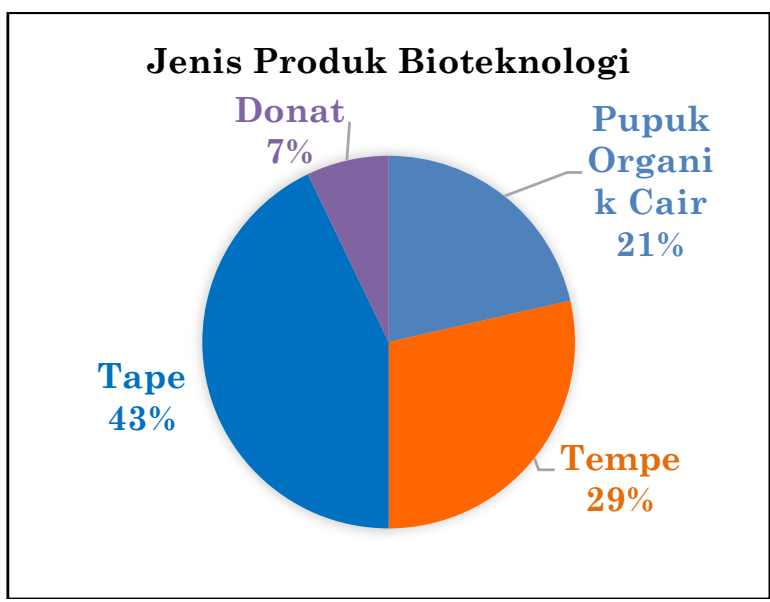

Gambar 2. Produk olahan yang berhasil dibuat mahasiswa IPA

Berdasarkan Gambar 3, mahasiswa IPA di IAIN Ponorogo selama pembelajaran daring bioteknologi telah mampu mengaplikasikan ide-ide kreatif mereka menjadi produk yang bermanfaat dan berbeda dari pada umumnya yang ada di masyarakat luas. Adanya pemikiran mengenai perbaikan gizi atau fortifikasi pada produk olahan makanan menjadi suatu keunggulan dari produk yang mereka hasilkan. Sebanyak $43 \%$ mahasiswa IPA mengaku berhasil membuat produk olahan makanan tape namun dengan variasi yang berbeda. Mahasiswa IPA yang berhasil membuat produk makanan tempe sebanyak 29\% dan mereka tetap memiliki ciri khas masing-masing, terutama dari bahan baku yang digunakan. Pada produk olahan donat sebanyak 7\%. Selain itu terdapat $21 \%$ responden yang memanfaatkan bioteknologi pada dunia pertanian yaitu dengan pembuatan pupuk organik cair (POC) dari limbah di sekitar lingkungan.

Respon mahasiswa IPA mengenai produk hasil selama melakukan pembelajaran daring pada mata kuliah bioteknologi dapat dilihat pada Tabel 2 .

Tabel 2. Produk bioteknologi hasil karya mahasiswa IPA IAIN Ponorogo selama pembelajaran daring

\begin{tabular}{ll}
\hline No & Produk bioteknologi \\
\hline 1 & $\begin{array}{l}\text { Pupuk organik cair dari limbah kulit } \\
\text { singkong }\end{array}$ \\
2 & Pupuk organik cair dari kulit pisang \\
3 & Pupuk organik cair dari limbah dapur \\
\hline
\end{tabular}




\begin{tabular}{ll}
\hline No & Produk bioteknologi \\
\hline & rumahan \\
4 & Milkshake tape ketan hitam \\
5 & Katsu tempe \\
6 & Brem tape ubi \\
7 & Ice cream tapai ketan hitam \\
8 & Tempe GAKUN (mangga sukun) \\
9 & Tempe kacang hijau \\
10 & Tempe jagung \\
11 & Donat ubi ungu \\
12 & ODCATO (odading tape isi coklat) \\
13 & TETAPI (tape talas daun pandan hijau) \\
14 & Gabin tapai nasi dengan fortifikasi \\
& daun pandan \\
\hline
\end{tabular}

Berdasarkan Tabel 2, dalam praktik selama pembelajaran daring bioteknologi mereka bukan hanya semata-mata membuat produk olahan saja, akan tetapi juga harus melakukan uji organoleptik terkait dengan hasil karya buatan mereka. Misalnya pada produk berupa TETAPI (tape talas daun pandan hijau) menurut responden yang telah melakukan uji organoleptik terkait olahan makanan tersebut menyatakan bahwa mayoritas panelis menyukai produk tersebut. Dengan demikian dapat menjadi suatu indikator bahwa produk olahan tersebut dapat diterima oleh masyarakat. Mahasiswa IPA dapat membuat produk olahan yang inovatif dengan memanfaatkan bahan dari lingkungan sekitar mereka. Inovasi berupa penggunaan bahan lokal menjadi alternatif yang banyak diproduksi oleh mahasiswa IPA. Selain itu, adanya ide dalam hal fortifikasi menjadi perhatian tersendiri. Hal tersebut dikarenakan produk olahan makanan yang mereka produksi lebih memperhatikan kandungan gizi sehingga dengan adanya produk tersebut dapat menjadi salah satu cara untuk melengkapi kebutuhan gizi jika dikonsumsi oleh masyarakat luas.

Respon mahasiswa mengenai ketersedian produk bioteknologi yang serupa di pasaran luas dapat dilihat pada Gambar 4.

\section{Ketersediaan Produk Serupa Bioteknologi Di Pasaran}

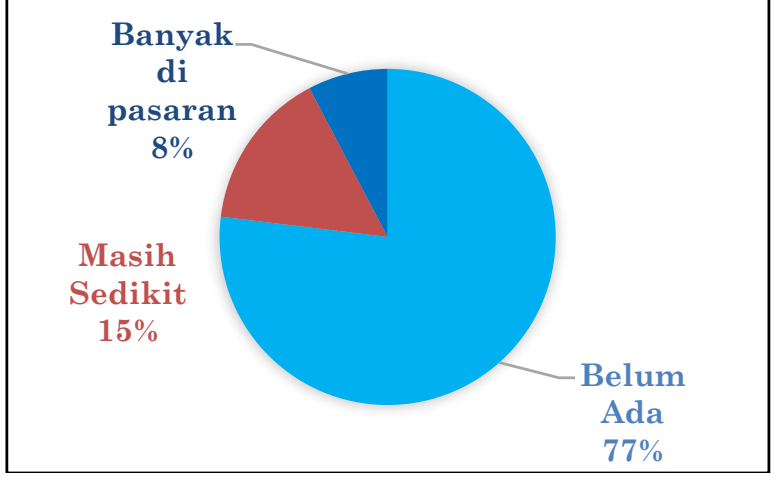

Gambar 3. Ketersediaan produk serupa di pasaran

Berdasarkan Gambar 4, dapat diketahui bahwa produk bioteknologi yang berhasil dibuat oleh mahasiswa IPA rata-rata belum ada dipasaran. Sebanyak $77 \%$ produk yang dihasilkan belum beredar di masyarakat. Hal tersebut membuktikan bahwa produk yang dihasilkan oleh mahasiswa IPA merupakan karya inovatif yang memiliki potensi untuk dikembangkan. Sedangkan $15 \%$ dari produk yang dihasilkan oleh mahasiswa IPA sudah ada di masyarakat akan tetapi masih sedikit jumlahnya. Namun masih terdapat produk yang sudah banyak beredar di masyarakat yaitu sebesar 8\%. Meskipun demikian dengan adanya fortifikasi pada produk olahan khususnya pada jenis makanan sehingga tetap memiliki nilai positif dari produk yang sudah ada.

\section{Pengembangan Produk Bioteknologi}

Menurut Dr. Ir. Haryono (dalam Fuad, 2004) mengemukakan bahwa hal mendasar dalam pengembangan bioteknologi ialah menyesuaikan dengan arah pengembangan dan peningkatan produktivitas bahan pangan dunia. Bahkan menurut Nurmemmedov (dalam (Machin, 2012) menjelaskan bahwa pengembangan produk bioteknologi di beberapa kawasan negara maju merupakan suatu prioritas dengan melakukan kegiatan bioekonomi atau pengembangan produk ekonomi yang berasal dari teknologi biologi. Adanya produk olahan dari bioteknologi yang telah berhasil dibuat oleh mahasiswa IPA 
IAIN Ponorogo selama pembelajaran daring membuat mereka berkeinginan untuk dapat mengembangkan hasil praktiknya. Salah satunya ialah dalam hal wirausaha, hal tersebut berdasarkan hasil uji organoleptik yang telah mereka lakukan mendapatkan respon positif dari masyarakat ditandai dengan banyaknya yang menyukai produk olahan mereka, khususnya berupa makanan. Produk hasil olahan yang berhasil dibuat merupakan jenis olahan yang belum ada di pasaran. Kandungan gizi yang lebih baik dari produk olahan lain yang serupa menjadi nilai positif tersendiri dari produk olahan mereka. Hal tersebut dikarenakan dalam pembuatannya, responden mengaku selain mengutamakan kreativitas namun juga memperhatikan perbaikan gizi atau fortifikasi dari produk olahan mereka. Dengan demikian produk olahan berupa makanan dari mereka bukan hanya memiliki keunikan tetapi juga adanya perbaikan kandungan gizi di dalamnya sehingga menjadi daya tarik tersendiri untuk dapat dikembangkan khususnya dalam bidang wirausaha kuliner.

Produk yang dihasilkan dari mahasiswa IPA rata-rata berasal dari bahan lokal atau dari lingkungan sekitar. Hal tersebut dikarenakan selain adanya efek pandemi Covid-19 yang membatasi masyarakat untuk keluar rumah, tetapi juga untuk mengoptimalkan bahan lokal di lingkungan sekitar. Pemanfaatan sumber bahan lokal sebagai bahan utama yang mudah ditemukan menjadi produk yang memiliki manfaat yang besar merupakan salah satu kekuatan dalam pengembangan produk bioteknologi di masa yang akan datang. Pembuatan produk yang ramah lingkungan penting untuk diterapkan, maka dari itu mereka membuat produk yang dapat bermanfaat bagi manusia tanpa adanya efek buruk. Salah satu responden yang berhasil membuat produk bioteknologi berupa pupuk cair dari kulit singkong dan telah melalui proses uji coba untuk tanaman di sekitar rumahnya. Responden mengatakan bahwa ada perbedaan yang signifikan antara pupuk organik cair buatannya dengan pupuk anorganik, yaitu berupa pertumbuhan yang lebih cepat dan tanaman yang lebih subur dibandingkan dengan tanaman yang menggunakan pupuk anorganik. Dengan demikian produk bioteknologi berupa pupuk organik cair ini jika dikembangkan dalam skala yang lebih besar dapat mengatasi permasalahan dalam pertanian misalnya kelangkaan subsidi hingga kerusakan lingkungan akibat pupuk anorganik yang berlebihan.

Respon mahasiswa mengenai rencana pengembangan produk yang sudah dihasilkan selama pembelajaran bioteknologi dapat dilihat pada Gambar 5 .

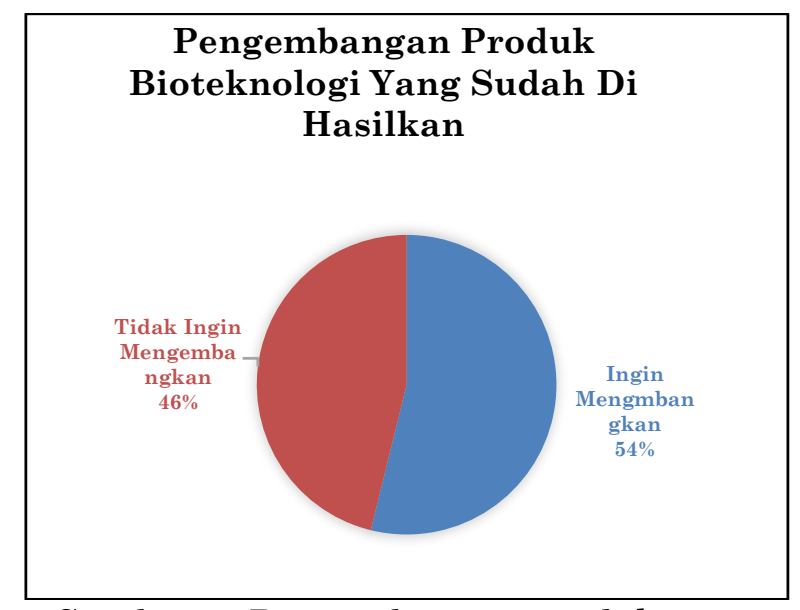

Gambar 4. Pengembangan produk yang dihasilkan

Berdasarkan Gambar 5, mahasiswa IPA bukan hanya memiliki keinginan untuk berwirausaha, tetapi juga ingin melakukan penelitian lebih lanjut mengenai pengembangan dari penerapan bioteknologi ini dalam kehidupan seharihari. Sebanyak 58\% responden berpendapat bahwa dengan mengetahui lebih banyak produk khususnya makanan yang dapat dibuat dengan menerapkan bioteknologi maka semakin banyak pula manfaatnya untuk kehidupan manusia dan mereka ingin mengembangkannya di kemudian hari. Mereka juga beranggapan bahwa dari keberhasilannya dalam membuat produk inovasi dari bioteknologi masih perlu diadakan penelitian lebih lanjut dengan berbasis ramah lingkungan yang mengutamakan kebermanfaatan bagi masyarakat luas. Penerapan bioteknologi dengan memanfaatkan sumber daya alam untuk dapat mendongkrak produk olahan baik dari 
segi kandungan gizi maupun nilai jualnya. Selain itu juga dapat mengoptimalkan sumber daya lokal yang dapat digunakan sebagai kekuatan untuk bersaing khususnya dalam bidang wirausaha pada abad 21 ini. Dengan demikian ide dan hasil terkait produk olahan hasil dari pembelajaran bioteknologi ini dapat digunakan sebagai acuan untuk lebih dikembangkan dikemudian hari khususnya dalam bidang wirausaha.

Sedangkan sebanyak $48 \%$ di antaranya masih belum memiliki keinginan untuk mengembangkan produk yang telah berhasil dibuat selama mengikuti pembelajaran bioteknologi. Mereka menyatakan bahwa produk yang dihasilkan hanya sebatas untuk memenuhi syarat pada pembelajaran mata kuliah bioteknologi. Oleh karena itu perlu adanya tindak lanjut pasca pembelajaran khususnya yang memiliki potensi untuk dikembangkan di masa yang akan datang.

\section{KESIMPULAN}

Berdasarkan pembahasan di atas dapat disimpulkan pembelajaran daring bioteknologi memiliki dampak yang baik terhadap kreativitas atau berpikir kreatif bagi mahasiswa IPA IAIN Ponorogo. Adanya hasil pemikiran mengenai ide atau gagasan baru mengenai inovasi produk bioteknologi baik dari bidang makanan ataupun pertanian menjadi indikator mahasiswa IPA mampu berpikir kreatif dengan baik. Mahasiswa IPA juga telah berhasil membuat sendiri produk hasil pemikiran mereka dan telah melakukan uji organoleptik. Selain itu, mereka juga mempunyai keinginan untuk dapat mengembangkan produk bioteknologi yang mereka ciptakan baik dalam bidang wirausaha maupun pengembangan untuk penelitian lebih lanjut. Keberhasilan membuat produk dari hasil pemikiran sendiri merupakan bukti bahwa dalam pembelajaran daring mata kuliah bioteknologi dengan menggunakan model Project Based Learning (PjBL) dapat membuat mahasiswa IPA IAIN Ponorogo meningkatkan dan mengembangkan kreativitas mereka. Adanya respon mengenai ketidakinginan untuk mengembangkan produk inovatif yang telah dihasilkan menjadi tantangan mengenai tindak lanjut pasca pembelajaran mata kuliah bioteknologi khususnya secara berkelanjutan. Sehingga mahasiswa IPA memiliki kemampuan untuk mengaplikasikan ilmu yang telah didapatkan dalam pembelajaran dalam kehidupan seharihari.

\section{DAFTAR PUSTAKA}

Antika, R. N., \& Nawawi, S. (2017). Pengaruh model project based learning pada mata kuliah seminar terhadap keterampilan berpikir kreatif mahasiswa. Jurnal Pendidikan Biologi Indonesia, 3(1), 72-79.

Budiana, I. M., Manuaba, I. B. S., \& Suadnyana, I. N. (2016). Model project based learning berbantuan media KIT IPA meningkatkan hasil belajar IPA. Mimbar PGSD Undiksha, 4(1), 1-12.

Chasanah, A. R. U., Khoiri, N., \& Nuroso, H. (2016). Efektivitas model project based learning terhadap keterampilan proses sains dan kemampuan berpikir kreatif siswa pada pokok bahasan kalor kelas X SMAN 1 Wonosegoro tahun pelajaran 2014/2015. Jurnal Penelitian Pembelajaran Fisika, 7(1), 19-24.

Farihatun, S. M., \& Rusdarti, R. (2019). Keefektifan pembelajaran project based learning (PJBL) terhadap peningkatan kreativitas dan hasil belajar. Economic Education Analysis Journal, 8(2), 635651.

Fuad, F. (2004). Perlindungan keanekaragaman hayati indonesia dari dampak negatif pengembangan produk bioteknologi pertanian modern. Lex Jurnalica, 1(3), 143-157.

Harahap, S. (2020). Identifikasi kreativitas siswa terhadap mata pelajaran IPA. Integrated Science Education Journal (ISEJ), 1(1), 16-22.

Ismayani, A. (2016). Pengaruh penerapan STEM project-based learning terhadap kreativitas matematis siswa SMK. Indonesian Digital Journal of Mathematics and Education, 3(4), 264272. 
Kemendikbud. (2014). Permendikbud RI Nomor 103 Tahun 2014 tentang pembelajaran pada pendidikan dasar dan pendidikan menengah. Jakarta: Kementerian Pendidikan dan Kebudayaan.

Kemendikbud. (2018). Permendikbud RI Nomor 35 Tahun 2018 tentang perubahan atas Permendikbud Nomor 58 Tahun 2014 tentang Kurikulum 2013 SMP/MTs. Jakarta: Kementerian Pendidikan dan Kebudayaan

Machin, A. (2012). Pengembangan model pembelajaran bioteknologi bervisi kewirausahaan di sekolah menengah atas. Bioedukasi, 5(2), 50-60.

Marlinda, N. L. P. M. (2020, November). Metode eksperimen berbantuan media phet dengan model pembelajaran PjBL. In Seminar Ilmiah Nasional Teknologi, Sains, dan Sosial Humaniora (SINTESA) (p. 295-300). Universitas Dhyana Pura.

Mulyadi, E. (2015). Penerapan model project based learning untuk meningkatkan kinerja dan prestasi belajar fisika siswa SMK. Jurnal Pendidikan Teknologi Dan Kejuruan, 22(4), 385-395.

Noviyana, H. (2017). Pengaruh model project based learning terhadap kemampuan berpikir kreatif matematika siswa. Jurnal e-DuMath, 3(2), 110-117.

Rahmazatullaili, R., Zubainur, C. M., \& Munzir, S. (2017). Kemampuan berpikir kreatif dan pemecahan masalah siswa melalui penerapan model project based learning. Beta: Jurnal Tadris Matematika, 10(2), 166183.

Siswono, T. Y. E. (2016, August). Berpikir kritis dan berpikir kreatif sebagai fokus pembelajaran matematika. In Seminar Nasional Matematika dan Pendidikan Matematika (1 ${ }^{\text {st }}$ SENATIK) (pp. 11-26). FPMIPATI-Universitas PGRI Semarang. 